\title{
FAKTOR DETERMINAN KEPATUHAN DIET PENDERITA HIPERTENSI
}

\author{
DETERMINAN FACTORS OF HYPERTENSION DIET PATIENTS
}

\author{
Kartin L. Buheli, Lisdiyanti Usman \\ Program Studi Keperawatan \\ Politeknik Kesehatan Gorontalo \\ usmanlisdiyanti@gmail.com
}

\begin{abstract}
Abstrak
Penelitian ini bertujuan untuk mengetahui faktor determinan yang berhubungan dengan kepatuhan diet penderita hipertensi di Puskesmas Kota Utara Kota Gorontalo. Metode penelitian ini menggunakan jenis penelitian survei analitik dengan pendekatan Cross sectional. Populasi dalam penelitian ini adalah seluruh penderita hipertensi diwilayah kerja Puskesmas Kota Utara sebanyak 331 penderita. Teknik sampling yang digunakan yaitu Proportionate Stratified Random Sampling. Jumlah sampel yang diteliti sebanyak 158 responden. Variabel yang digunakan adalah variabel bebas yakni motivasi diri, lama menderita penyakit, dukungan sosial keluarga dan dukungan tenaga kesehatan dan variabel terikat yakni kepatuhan diet hipertensi. Penelitian ini dilakukan pada tanggal 10 September 2018 sampai dengan 31 Oktober 2018. Hasil penelitian dan analisis dengan menggunakan uji statistik Chi Square dengan nilai signifikansi alpha 5\% $(\alpha=0,05)$. Kesimpulan dari penelitian ini adalah adanya hubungan antara motivasi diri $(p=0,000)$, lama menderita penyakit $(p=0,007)$, dukungan sosial keluarga $(p=0,004)$, dukungan tenaga kesehatan $(\mathrm{p}=0,001)$ dengan kepatuhan diet hipertensi diwilayah kerja Puskesmas Kota Utara Kota Gorontalo.
\end{abstract}

Kata Kunci: Kepatuhan diet, Hipertensi.

\begin{abstract}
The aim of this study was to observe the determinant factors that related with diet obedient on patient of hypertension in public health center of Kota Utara of Gorontalo city. The Method of this study was analytics survey with Cross sectional approach. The population of this study was all patients of hypertension in work area of kota utara as many as 331 sufferers. Sampling technique of this study was Proportionate Stratified Random Sampling. The number of respondent in this study was 158 respondents. The variable was independent variable such as self motivation, duration of suffering, social family support and health workers support and related variable which is the obedient of diet hypertension. This study was conducted on September 10 on 2018 until October 31on 2018. The result of this study and analysis are used Chi Square statistic test with significant result in alpha $5 \%(\alpha=0,05)$. The result of this study indicated that there was the relation between self motivation $(p=0,000)$, duration of suffering $(p=0,007)$, social family support $(p=0,004)$, health workers support $(p=0,001)$ with obedient of diet hypertension in work area of public health center of Kota Utara of Gorontalo city
\end{abstract}

Keywords: Diet Obedient, Hypertensi 


\section{Pendahuluan}

Pola kesakitan saat ini menunjukkan bahwa Indonesia mengalami double burden of disease dimana penyakit menular masih merupakan tantangan (walaupun telah menurun) tetapi penyakit tidak menular meningkat dengan tajam. Pada tingkat global, 63\% penyebab kematian di dunia adalah penyakit tidak menular yang membunuh 36 juta jiwa per tahun. Penyakit tidak menular adalah penyakit kronis dengan durasi yang panjang dengan proses penyembuhan atau pengendalian kondisi klinisnya yang umumnya lambat seperti hipertensi (Permenkes, 2017). Hipertensi masih merupakan tantangan besar di Indonesia. Hipertensi merupakan kondisi yang sering ditemukan pada pelayanan kesehatan primer. Hipertensi merupakan masalah kesehatan dengan prevalensi yang tinggi. Disamping itu, pengontrolan hipertensi belum kuat meskipun obat-obatan yang efektif banyak tersedia (Infodatin, 2014).

Berdasarkan data dari Riset Kesehatan Dasar (Riskesdas, 2013), hipertensi di Indonesia merupakan masalah kesehatan dengan prevalensi yang tinggi yaitu sebesar 25,8\%, prevalensi hipertensi di indonesia yang didapat melalui pengukuran pada kelompok umur $\geq 18$ tahun. Prevalensi tertinggi hipertensi di Indonesia terdapat di Bangka Belitung (30,9\%), diikuti Kalimantan Selatan (30,8\%), Kalimantan Timur (29,6\%), Jawa Barat $(29,4 \%)$, dan Gorontalo $(29,4 \%)$. Prevalensi hipertensi di Provinsi Gorontalo yang didapat melalui pengukuran pada umur $\geq 18$ tahun sebesar 29,0\%, tertinggi di Kabupaten Gorontalo (41,0\%), diikuti Bone Bolango (29,7\%), Kota Gorontalo (22,2\%) dan Gorontalo Utara $(22,1 \%)$ (Riskesdas, 2013).

Penatalaksanaan hipertensi dapat dilakukan dengan dua cara yakni cara farmakologi menggunakan obat-obatan dan non farmakologi yakni dengan modifikasi gaya hidup. Modifikasi gaya hidup dapat dilakukan dengan diet hipertensi diantaranya membatasi asupan garam, menurunkan berat badan, menghindari minuman berkafein, rokok, dan minuman beralkohol serta olahraga (Infodatin, 2014).
Data yang diperoleh dari dinas Kesehatan Provinsi Gorontalo di dapatkan hipertensi merupakan penyakit tidak menular tertinggi di seluruh wilayah Provinsi Gorontalo yakni dengan jumlah 29.391 kasus pada tahun 2016 (Dinas Kesehatan Provinsi Gorontalo). Tahun 2017 tercatat hipertensi menduduki peringkat kedua dari seluruh data kunjungan di seluruh Puskesmas di Kota Gorontalo, dan mengalami penigkatan dari 6.883 kasus pada tahun 2016 menjadi 9.366 kasus pada tahun 2017 terhitung dari bulan JanuariDesember. Berdasarkan jenis kelamin hipertensi pada laki-laki sebesar 3.519 kasus dan pada perempuan sebesar 5847 kasus di tahun 2017 (Dinas Kesehatan Kota Gorontalo).

Data di Puskesmas Kota Utara pada bulan Januari-November tahun 2017 didapatkan sebanyak 331 penderita hipertensi di 6 kelurahan dengan rincian sebagai berikut: Kelurahan Dembe II sebanyak 22 orang, Kelurahan Wongkaditi Timur sebanyak 91 orang, Wongkaditi Barat sebanyak 16 orang, Kelurahan Dulomo Selatan sebanyak 55 orang, Kelurahan Dulomo Utara sebanyak 119 orang, dan Kelurahan Dembe Jaya sebanyak 28 orang. Berdasarkan data kunjungan penyakit hipertensi di Wilayah Puskesmas Kota Utara pada tahun 2017 berjumlah 1.723 kunjungan.

\section{Metode}

Jenis penelitian ini adalah survei analitik dengan pendekatan Cross sectional. Penelitian ini dilaksanakan di wilayah kerja Puskesmas Kota Utara pada tanggal 10 September 2018 sampai dengan 31 Oktober 2018. Populasi penelitian ini adalah semua penderita hipertensi di wilayah kerja Puskesmas Kota Utara Kota Gorontalo pada bulan Januari sampai dengan bulan November tahun 2017 sebanyak 331 penderita hipertensi lama dan baru. Yang berada di 6 kelurahan di kecamatan Kota Utara yakni di Kelurahan Dembe II sebanyak 22 orang, Kelurahan Wongkaditi Timur sebanyak 91 orang, Wongkaditi Barat sebanyak 16 orang, Kelurahan Dulomo Selatan sebanyak 55 orang, Kelurahan Dulomo Utara sebanyak 119 
orang, dan Kelurahan Dembe Jaya sebanyak 28 orang. Pengambilan sampel dalam penelitian ini dihitung berdasarkan rumus Nomogram Harry King yaitu jumlah Sampel $=$ Presentase $\mathrm{x}$ Populasi $\mathrm{x}$ Faktor pengali Sampel $=0,40 \times 331 \times 1,195$ sehingga didapatkan jumlah Sampel = 158,218 dibulatkan menjadi 158. Untuk angka presentasi diambil dari angka 331 melewati taraf kesalahan 5\%, maka akan ditemukan titik di angka 40. Sehingga presentase populasi yang diambil adalah $40 \%$ atau 0,40. Jadi jumlah sampel dalam penelitian ini adalah 158 penderita hipertensi.

\section{Hasil}

\section{Motivasi diri}

Sebanyak $34,2 \%$ penderita hipertensi di wilayah kerja Puskesmas Kota Utara tidak ada motivasi diri untuk melaksanakan diet hipertensi. Hal ini dikarenakan kurangnya minat dan kemauan dari dalam diri serta kurangnya dukungan dari lingkungan sosial.

\section{Lama menderita hipertensi}

lebih dari sebagian responden lama menderita hipertensi >5 tahun yakni sebanyak $50,6 \%$ dan sebanyak $49,4 \%$ responden menderita hipertensi dengan lama menderita $\leq 5$ tahun.

\section{Dukungan sosial keluarga}

Sebanyak $31 \%$ reponden tidak ada dukungan sosial keluarga dalam melaksanakan diet. Hal ini disebabkan kurangnya pengawasan serta keterlibatan keluarga dalam diet yang dilaksanakan oleh responden.

\section{Dukungan tenaga kesehatan}

Sebanyak 34,8\% responden penelitian tidak ada dukungan dari tenaga kesehatan. Hal ini disebabkan kurangnya penyuluhan terkait diet hipertensi serta keterlibatan keluarga dalam diet yang dilaksanakan oleh penderita.

\section{Kepatuhan diet}

Sebanyak 44,3\% responden tidak patuh dalam melaksanankan diet hipertensi.
Hal ini dikarenakan beberapa responden belum sepenuhnya mematuhi diet karena kebiasaan masyarakat masih mengkonsumsi makanan yang digoreng, serta kurangnya konsumsi buah dan sayur setiap hari. Hasil penelitian yang di dapatkan responden masih mengkonsumsi makanan yang tidak dianjurkan dalam diet atau makanan yang harus dibatasi dengan alasan makanan akan hambar jika mengurangi pemakaian garam, selain itu makanan responden biasanya dimasak bersama dengan makanan anggota keluarga lainnya sehingga lebih cenderung mengikuti selera dari anggota keluarga dan tidak memperhatikan diet yang dilaksanakannya.

Analisis bivariat digunakan untuk menganalisis hubungan antara faktor determinan yang berhubungan dengan kepatuhan yakni motivasi diri, lama menderita penyakit, dukungan sosial keluarga dan dukungan tenaga kesehatan dengan kepatuhan diet penderita hipertensi diwilayah kerja Puskesmas Kota Utara tahun 2018 dengan menggunakan uji Chi Square.

\section{Hubungan antara motivasi diri dengan kepatuhan diet penderita hipertensi}

Sebanyak 88 responden patuh dalam menjalakankan diet hipertensi dengan ada motivasi diri sebanyak 72 responden dan yang tidak ada motivasi diri sebanyak 16 responden. Sementara itu sebanyak 70 responden tidak patuh dalam menjalankan diet dengan yang memiliki motivasi sebanyak 32 responden dan tidak memiliki motivasi sebanyak 38 responden. Hasil analisis data dengan menggunakan uji statistik Chi Square maka diperoleh p value 0,000 dengan $\alpha=0,05$ dimana 0,000 lebih kecil dari $0,05(0,000<0,05)$ ini berarti Ho ditolak dan Ha diterima atau ada hubungan antara motivasi diri dengan kepatuhan diet penderita hipertensi diwilayah kerja Puskesmas Kota Utara Kota Gorontalo.

Berdasarkan uji Chi Square di dapatkan hasil $\chi^{2}$ hitung $=22,59$, maka $\mathrm{H}_{0}$ ditolak karena $\chi^{2}$ hitung $\geq \chi^{2}$ tabel didapatkan hasil 22,59>3,841, sehingga $\mathrm{H}_{0}$ ditolak dan $\mathrm{H}_{\mathrm{a}}$ diterima. 
Hubungan antara lama menderita penyakit dengan kepatuhan diet penderita hipertensi

Sebanyak 88 responden patuh dalam menjalakankan diet dengan lama menderita hipertensi $>5$ tahun sebanyak 53 responden dan lama menderita hipertensi $\leq 5$ tahun sebanyak 35 responden. Sementara itu sebanyak 70 responden tidak patuh dalam menjalankan diet dengan lama menderita hipertensi $>5$ tahun sebanyak 27 responden dan lama menderita hipertensi $\leq 5$ tahun sebanyak 43 responden. Hasil analisis data dengan menggunakan uji statistik Chi Square maka diperoleh $\rho$ value $=0,007$ dengan $\alpha=5 \%$ dimana 0,007 lebih kecil dari $0,05(0,007<0,05)$ ini berarti Ho ditolak dan Ha diterima atau ada hubungan antara lama menderita penyakit dengan kepatuhan diet penderita hipertensi diwilayah kerja Puskesmas Kota Utara Kota Gorontalo. Berdasarkan uji Chi Square didapatkan hasil $\chi^{2}$ hitung $=7,315$. maka Ho ditolak karena $\chi^{2}$ hitung $\geq \chi^{2}$ tabel didapatkan hasil 7,315> 3,841 sehingga $\mathrm{H}_{0}$ ditolak dan $\mathrm{H}_{\mathrm{a}}$ diterima.

Hubungan antara dukungan sosial keluarga dengan kepatuhan diet penderita hipertensi.

Sebanyak 88 responden patuh dalam menjalakankan diet dengan responden yang mendapat dukungan dari keluarga sebanyak 69 responden dan responden yang tidak ada dukungan keluarga sebanyak 19 responden. Sementara itu sebanyak 70 responden tidak patuh dalam menjalankan diet yakni dengan responden yang ada dukungan sosial keluarga sebanyak 40 responden dan yang tidak ada dukungan sosial keluarga sebanyak 30 responden. Hasil analisis data dengan menggunakan uji statistik Chi Square maka diperoleh $\rho$ value $=0,004$ dengan $\alpha=0,05$ dimana 0,004 lebih kecil dari $0,05(0,004<0,05)$ ini berarti $\mathrm{H}_{0}$ ditolak dan $\mathrm{H}_{\mathrm{a}}$ diterima atau ada hubungan antara dukungan sosial keluarga dengan kepatuhan diet penderita hipertensi diwilayah kerja Puskesmas Kota Utara Kota Gorontalo. Berdasarkan uji Chi Square manual di dapatkan hasil $\chi^{2}$ hitung $=8,241$. maka $\mathrm{H}_{0}$ ditolak karena $\chi^{2}$ hitung $\geq \chi^{2}$ tabel didapatkan hasil $8,241>3,841$

sehingga $\mathrm{H}_{0}$ ditolak dan $\mathrm{H}_{\mathrm{a}}$ diterima.

\section{Hubungan antara dukungan tenaga kesehatan dengan kepatuhan diet penderita hipertensi.}

Sebanyak 88 responden patuh dalam menjalakankan diet dengan responden yang ada dukungan dari tenaga kesehatan sebanyak 67 responden dan responden yang tidak ada dukungan tenaga kesehatan sebanyak 21 responden. Sementara itu sebanyak 70 responden tidak patuh dalam menjalankan diet yakni dengan responden yang ada dukungan tenaga kesehatan sebanyak 36 responden dan yang tidak ada dukungan tenaga kesehatan sebanyak 34 responden. Hasil analisis data dengan menggunakan uji statistik Chi Square maka diperoleh $\rho$ value $=0,001$ dengan $\alpha=0,05$ dimana 0,001 lebih kecil dari 0,05 $(0,001<$ $0,05)$ ini berarti Ho ditolak dan Ha diterima atau ada hubungan antara dukungan tenaga kesehatan dengan kepatuhan diet penderita hipertensi diwilayah kerja Puskesmas Kota Utara Kota Gorontalo. Berdasarkan uji Chi Square didapatkan hasil $\chi^{2}$ hitung $=10,48$. Maka $\mathrm{H}_{0}$ ditolak karena $\chi^{2}$ hitung $\geq \chi^{2}$ tabel didapatkan hasil $10,48>3,841$ sehingga $\mathrm{H}_{0}$ ditolak dan $\mathrm{H}_{\mathrm{a}}$ diterima.

\section{Kesimpulan}

Terdapat pengaruh signifikan dari jumlah keseluruhan sampel yang dijadikan responden yaitu motivasi diri, lama menderita hipertensi, dukungan sosial keluarga dan dukungan tenaga kesehatan pada klien yang menderita hipertensi di wilayah kerja puskesmas kota Utara kota Gorontalo.

\section{Saran}

Petugas kesehatan diharapkan lebih meningkatkan intervensi khususnya penyuluhan kesehatan tentang kepatuhan diet pada klien hipertensi serta dampak yang akan ditimbulkan jika tidak mentaati diet tersebut.

\section{Daftar Pustaka}

Badan pusat statistik Kota Gorontalo, 2017. Kecamatan Kota Utara dalam Angka. 
dalam https://gorontalokota.bps.go.id diakses tanggal 11 Januari 2018

Imran, Ali. 2017. Hubungan Dukungan

Keluarga dengan Kepatuhan

Pengendalian Hipertensi pada Lansia di Puskesmas Pandak 1 Bantul Yogyakarta. Skripsi.Stikes Jendral Achmad Yani Yogyakarta

Kemenkes, RI. 2014. INFODATIN (Pusat

Data dan Informasi Kementerian

Kesehatan Republik Indonesia)

HIPERTENSI. Jakarta.

http://www.pusdatin.kemkes.go.id

diakses tanggal 12 Januari 2018

Kementerian Kesehatan. 2015. Peraturan

Menteri Kesehatan Republik

Indonesia Nomor 71 Tahun 2015

Tentang Penanggulangan Penyakit

Tidak Menular.

http://p2ptm.kemkes.go.id diakses tanggal 12 Januari 2018

Kementrian Kesehatan RI. 2013. Riset

Kesehatan Dasar 2013.

http://www.litbang.depkes.go.id

diakses tanggal 8 Januari 2018 